\title{
ECOLOGY
}

\section{Insects used for animal feed in West Africa}

\author{
M. Kenis, ${ }^{1}$ N. Koné, ${ }^{2}$ C.A.A.M. Chrysostome, ${ }^{3}$ E. Devic, ${ }^{4}$ G.K.D. Koko, ${ }^{5}$ V.A. Clottey, ${ }^{6}$ \\ S. Nacambo, ${ }^{1}$ G.A. Mensah ${ }^{7}$
}

'CABI, Delémont, Switzerland; ' Institut d'Economie Rurale, Centre Régional de Recherche Agricole de Sotuba, Bamako, Mali; ${ }^{3}$ University of Abomey-Calavi, République du Bénin; ${ }^{4}$ Institute of Aquaculture, University of Stirling, United Kingdom; ${ }^{5}$ Fish for Africa-Ghana, Accra, Ghana; ${ }^{6} \mathrm{CAB}$, CSIR Campus, Accra, Ghana; ${ }^{7}$ Institut National des Recherches Agricoles du Bénin, République du Bénin

\begin{abstract}
In West Africa, as in many parts of the world, livestock and fish farming suffer from the increasing cost of feed, especially protein ingredients, which are hardly available for village poultry farming and smallscale fish farming. Insects, which are a natural food source of poultry and fish and are rich in protein and other valuable nutrients, can be used to improve animal diets, a practice which is now strongly promoted by the FAO as a tool for poverty alleviation. This paper reviews practices and research on the use of insects as animal feed in West Africa and the perspectives to further develop the techniques, in particular for smallholder farmers and fish farmers. The most promising insects are flies, especially the house fly (Musca domestica) (Diptera Muscidae) and the black soldier fly (Hermetia illucens) (Diptera Stratiomyiidae), which can be mass reared on-farm for domestic use, in small production units at the community or industrial level. Flies have the advantage
\end{abstract}

\footnotetext{
Correspondence: Marc Kenis, CABI, Rue des Grillons 1, 2800 Delémont, Switzerland

Tel.: +41.32.421.4884.

E-mail:m.kenis@cabi.org

Key words: insects as feed, Musca domestica, Hermetia illucens, termites, poultry, aquaculture.

Acknowledgements: the study was carried out in the framework of the CABI CDF project Use of insects for animal feed in Africa and the EU FP7 project PROTEINSECT (Grant agreement no: 312084). We thank Erica Chernoh, Janet Stewart and Frances Williams for their comments on the manuscript.

Contributions: the authors contributed equally.

Received for publication: 16 April 2014

Revision received: 3 September 2014.

Accepted for publication: 3 September 2014.

This work is licensed under a Creative Commons Attribution NonCommercial 3.0 License (CC BY-NC 3.0).

(ㄷ) Copyright M. Kenis et al., 2014

Licensee PAGEPress, Italy

Entomologia 2014; 2:218

doi:10.4081/entomologia.2014.218
}

over most other insects of developing on freely available waste material and could even contribute to rural sanitation. Termites are traditionally used by smallholder farmers to feed village poultry. While their mass production is problematic, methods to enhance populations on-farm and facilitate collection can be developed. In any case, new methods will need to demonstrate their economic profitability, social acceptability and environmental sustainability.

\section{Introduction}

Global demand for animal-source foods is accelerating rapidly due to population growth and economic development, particularly in developing countries (Godfray et al., 2010). In most animal production systems, feed takes the largest part of the costs. Fish meal and leguminous crops such as soya are key ingredients in animal feeds since they provide the necessary protein compounds. Most animals, in particular monogastrics, require proteins to compensate the inability to synthesize specific amino-acids. However, conventionally used protein ingredients are not ecologically or economically sustainable (Barona et al., 2010; FAO, 2012). The issue is especially severe in rural West Africa, where feed compounds, in particular proteins, are scarce or unaffordable for smallholder farmers and fish producers. Indigenous poultry farming is practiced by almost all farmers in West Africa. Their main challenge is the increasing cost of feed, which represents up to $70 \%$ of the total production costs (Omole et al., 2005). A key issue is the limited availability of common protein ingredients (fish meal, groundnut cake and soybean) that have become particularly expensive. Scavenging poultry farming of poor households particularly suffers from quantitative and qualitative food shortages and, consequently, the productivity is very low (Hardouin, 2003; Pousga et al., 2005). Similarly, to feed their fish, smallholder fish farmers rely on natural productivity, i.e. phyto- or zooplankton, of the water bodies, or fertilize the ponds using manures or agricultural by-products. The nutritional value of these kinds of feed and feeding systems is low, which results in slow growth and poor yield (Rhodes University, 2010).

A solution to develop sustainable and productive household aviculture and aquaculture systems includes the use of local, easily available and cheap protein sources, preferably not used for other purposes. Insects, which are a natural food source of free range poultry and fish, provide a sustainable alternative to traditional protein sources (Hardouin \& Mahoux, 2003). Insect larvae and pupae are typically rich in protein (40-70\% dry weight), mono- and/or polyunsaturated fatty 
acids, other valuable nutrients such as iron, copper, magnesium, manganese, phosphorous, selenium, zinc, B vitamins and essential amino acids such as lysine and tryptophan (DeFoliart 1995; Rumpold \& Schlüter, 2013) and can be mass produced regionally and even on-farm (Hardouin \& Mahoux, 2003). The FAO strongly recommends the use of insects as human food and animal feed as a tool for poverty alleviation (FAO 2010; van Huis et al., 2013). Many insects are potentially suitable for animal feed (van Huis et al., 2013). In many parts of the world, e.g. Asia, several insect species have been used as complementary food sources, in particular for poultry (Ravindran \& Blair, 1993; van Huis et al. 2013). In West Africa, when available, several insect species are opportunistically given to livestock by farmers during outbreaks (e.g. grasshoppers). However, few insects are provided as feed in routine animal husbandry. Exceptions include termites and maggots. This paper reviews the use of insects as animal feed in West Africa with examples from Central African countries when appropriate. It covers research being carried out in the region, and perspectives on how to further develop the techniques, in particular for smallholder farmers and fish farmers.

\section{Termites}

Termites are highly nutritious insects (Redford \& Dorea, 1984; Sogbesan \& Ugwumba, 2008; Ntukuyoh et al., 2012). Throughout West Africa, they are collected in the bush to feed poultry. For example, $72 \%$ of the farmers in South-Western Burkina use termites to feed poultry (Diawara, 2013). Chippings of termite mounds or underground nests are collected and given to poultry on-farm, particularly to chicks and keets (young guinea fowls). This activity is often done by children who sometimes also sell the chippings to other users. Termites are not equally available in all regions and seasons, and in many cases collectors have to walk long distances to find sufficient amounts of termites to feed the farm animals. The difficulty of finding termites sometimes forces farmers to abandon this ancestral technique (Diawara, 2013).

According to farmers, not all termites are appropriate for poultry feed. For example, in Burkina Faso, some species of Cubitermes are reported as toxic to chicks, but not to guinea fowls and ducks (Diawara, 2013). In a feeding trial with chicks and keets in Benin, Chrysostome (1997) showed that a humivorous species of the genus Noditermes was toxic to both poultry species, in contrast to a xylophagous species, Trinervitermes sp., confirming farmers' knowledge. Feeding keets and chicks with the nontoxic species resulted in similar growth and survival compared to conventional feed.

Termites cannot be easily produced and moreover, their rearing produces high amounts of methane, an important greenhouse gas. However simple methods have been developed to increase the number of termites available on farm. Farina et al. (1991) and Vorsters et al. (1994) describe in detail methods used in Togo and Benin, which is based on fibrous and humidified waste or crop residues placed in clay pots or baskets, which are then inverted and placed on small termite nests. The pots are moistened regularly and protected from excess heating. Termites are collected in the pots after three to four weeks. Chrysostome et al. (2009) describe a similar technique used in Benin for collecting termites for keets. Maize or sorghum straw are placed in empty palmyra palm nuts (Borassus spp.), which are then put in moistened pots filled with bark pieces of locust bean (Parkia biglobosa) and sorghum straw. The pots as placed on nontoxic termite nests. The day after, termites are collected in the nuts and given to keets, preferably with grains. Other, similar techniques used in Burkina Faso are described in Diawara (2013).

To our knowledge, the only quantitative study on the effect of a termite diet on poultry growth in West Africa is that of Diawara (2013) in
Burkina Faso. She substituted fish meal by fresh termites of the genus Macrotermes in chick diets without affecting the daily weight gain, although the feed conversion ratio was significantly higher with termites compared to fish meal. Similarly, Munyuli Bin Mushambanyi \& Balezi (2002) showed, in the Democratic Republic of the Congo, that chick feed portions containing $12 \%$ of termite (Kalotermes flavicollis) meal gave satisfactory result in terms of mean weight gain and were economically much more profitable than conventional meat meal.

Termites are also used occasionally by smallholder fish farmers, although it is not clear to what extent this practice occurs in West Africa. In Uganda, about five per cent of fish farmers use termites as supplementary feed (Rutaisire, 2007). Termites are either collected directly or purchased from collectors at a cost of US Dollars $0.27 / \mathrm{kg}$ (at 2004 value). The quantity available depends on, among other things, the season, the availability of termite mounds and the termite species. On average, a termite mound provides about $50 \mathrm{~kg}$ of termites per year (Rutaisire, 2007).

Reproductive winged termites swarm in very high numbers at the onset of the rainy season or after heavy rainfall. Fish are often observed consuming winged termites when they fall into ponds. Sogbesan \& Ugwumba (2008) suggested that they could be used to prepare termite meal as a replacement to fish meal. They tested termite meal from oven-dried reproductive adults of Macrotermes subhyalinus and obtained excellent results on fingerlings of Heterobranchus longifilis, a commonly cultured catfish in Nigeria. The best results, in terms of growth rate and benefit-cost ratio, were obtained when combining $50 \%$ termite meal with $50 \%$ fish meal.

\section{House fly larvae}

Two species of flies have been extensively studied worldwide for their use in livestock feed; the domestic fly Musca domestica (Muscidae) and the black soldier fly Hermetia illucens (Stratiomyidae). In West Africa, M. domestica is more commonly used because of its prevalence in most habitats, its fast development, and the possibility of obtaining high numbers of maggots and pupae naturally on various substrates without having to rear adults for egg laying.

There is an extensive literature from West Africa on the suitability of maggots or pupae of $M$. domestica to rear chicks and broilers (Atteh \& Ologbenla, 1993; Bamgbose 1999; Akpodiete \& Inoni 2000; Téguia et al., 2002; Awoniyi et al. 2003; Adeniji, 2007; Adesina et al., 2011), layers (Akpodiete et al., 1998; Agunbiade et al., 2007; Okah \& Onwujiariri 2012), ducklings (Mensah et al., 2007), piglets (Adeniji, 2008), catfish species (Fasakin et al., 2003; Idowu et al., 2003; Madu \& Ufodike, 2003; Sogbesan et al., 2006; Oyelese 2007; Aniebo et al., 2011; Olele 2011; Kareem \& Ogunremi, 2012; Ossey et al., 2012), Nile tilapia (Ebenso \& Udo, 2003; Ogunji et al. 2006, 2007; 2008a; 2008b; 2009; Omoyinmi \& Olaoye 2012), carp (Ogunji et al., 2011) and African giant snail (Mbunwen et al., 2011). In all cases, these studies showed that maggots, either fresh or dried, could entirely or partially replace conventional protein ingredients such as fish meal, meat meal or groundnut cake without affecting survival, daily feed intake, weight gain, feed conversion ratio, egg laying and other performance factors. Some studies showed better results with maggot meal than with conventional fish meal (e.g. Téguia et al., 2002). However, when various proportions of maggot and fish, or maggot and meat meals were used, the best growth performance was often observed with variable combinations of maggot meal and conventional meal than with a single protein source. This may be because the combination of maggot meal with conventional feed might provide a more balanced diet for the animals. For example, Atteh \& Ologbenla (1993) found that a $33 \%$ replacement of conventional fish meal by maggot meal is ideal for chicks, but higher proportions of maggots reduced 
feed intake and growth. However, they used processed maggots, which has a dark color, and suggested that the observed reduction in feed intake associated with an increase in maggot meal proportions may simply be due to changes in feed color. In some cases, the optimum proportion depends on the age of the animals. Awoniyi et al. (2003) found better results by replacing conventional fish meal with $25 \%$ maggot meal than with $100 \%$ replacement in older broilers, while young broilers had no reduction in growth with a total replacement compared to mixtures. Similarly, in fish feeding tests, several authors found better results when giving a mixture of fish and maggot meal than with one protein source alone (Sogbesan et al., 2006; Madu \& Ufodike, 2003; Oyelese, 2007; Kareem \& Ogunremi, 2012).

In some cases, further processing maggot meals may be beneficial. Fasakin et al. 2003 showed that catfish performed better when fed diets containing defatted maggot meals than full-fat maggot meal, and compared favorably with fish fed the fish meal-based diet. Adding other supplements may also increase performances. Bamgbose (1999) showed that maggots can completely replace meat meal in diets for cockerel chicks without any adverse effect on performance and nutrient utilization, but that supplementation with methionine $(0.20 \%)$ enhanced nutrient utilization and performance significantly.

Many of the above cited studies also mentioned an economic benefit in the replacement of conventional protein sources by maggots (e.g. Atteh \& Ologbenla, 1993; Akpodiete \& Inoni 2000; Téguia et al., 2002; Sogbesan et al. 2006; Oyelese 2007; Okah \& Onwujiariri 2012). Cost saving can be substantial. For example, Atteh \& Ologbenla (1993) calculated that maggot meal represents only about $15 \%$ of the value of fish meal and Akpodiete \& Inoni (2000) increased the net return of broiler production by $15 \%$ when replacing $75 \%$ of fish meal by maggot meal. However, none of these studies provide adequate economic analyses because maggots were produced for the purpose of the experiments, in very small quantities and without attempt to minimize production costs or to assess the potential costs of larger production systems. These studies also virtually focused exclusively on industrial or semi-industrial battery poultry and fish production, where protein ingredients are always included in diets. In contrast, free-range domestic fowls scavenge around the farm, in streets and in the bush, where protein sources are rare. In such case, providing maggots or other insect-feed is even more profitable, but quantified studies in these environments are rare. An exception is that of Dankwa et al. (2002) in Ghana, who observed a significant increase in performance in chickens (clutch size, egg weight, number of eggs, hatched, and chick weight) fed with larvae compared to scavenging chicken.

There are few publications on fly rearing techniques in West Africa (Aniebo et al., 2008b). Most studies focusing on the use of domestic flies as animal feed cited in the preceding paragraphs obtained maggots by exposing small quantities of various substrates to naturally occurring flies. Larger scale production systems from Benin (Nzamujo, 1999) and Mali (Koné, 1998) have been described but the recommendations have not been substantiated by research data. The production systems are based on the exposure of substrates, placed on rearing beds directly on the soil, to attract adults for oviposition. A few days later, the substrate is sifted or brushed to extract mature maggots, which are either sun dried or given fresh to the animals. About 10-15 $\mathrm{kg}$ of dry matter in $1 \times 1 \times 0.1 \mathrm{~m}$ beds produce up to 3 or $4 \mathrm{~kg}$ of fresh maggots in 4 days (Nzamujo, 1999; Koné, unpublished data), but yields greatly vary with seasons and substrates. This system can be done at a small scale to feed a few chickens or at a larger scale to feed chicken or fish production farms. Rearing substrates have to be attractive for adults and suitable for maggot development. The most common substrates include poultry or other animal manure, animal offal, rumen content, brewery waste, decaying fruits, etc. Using a similar technique, Aniebo et al. (2008b) used cow and goat blood from a Nigerian abattoir and mixed the blood with wheat bran, rice dust and saw dust. Mixtures of $25 \mathrm{~kg}$ blood and $5 \mathrm{~kg}$ wheat bran yielded an average of $7.16 \mathrm{~kg}$ of fresh maggots. They calculated that the abattoir could potentially produce nearly 2 tons per day. Abattoirs can also provide rumen content, which is also highly suitable for maggot rearing (Loa, 2000). In Côte d'Ivoire, Bouafou et al. (2006) tested different animal and vegetal substrates as attractants for flies. They found that animal offal attracted much more flies for oviposition and produced much more larvae than fermented vegetal substrates. They also found more Calliphora spp. (blow flies Calliphoridae) than Musca spp. in most samples, including some vegetal substrates. This suggests that many feeding trials carried out in the region and based on naturally exposed substrates have contained a certain amount of blow flies. However, Bouafou et al. (2006) did not test manure, which is the most commonly used rearing substrate in the published studies. Mpoame et al. (2004) exposed chicken manure and cow dung for fly oviposition and maggot production in Cameroon. They found out that chicken manure was much more efficient and obtained exclusively Muscidae of various but undetermined species. Loa (2000) reared only $M$. domestica and two individuals of Musca sorbens from rumen contents in Cameroon.

Studies on the chemical composition and nutrition parameters of house fly maggots and pupae are numerous and have been recently compiled by Awoniyi (2007), Bouafou (2011) and Heuzé \& Tran (2013a). Although results often varied significantly between studies, partly because the production methods were also variable, all studies show that maggots have a high crude protein content (40 to $60 \% \mathrm{DM}$ ) and lipid content (9 to 25\% DM). Research data from West Africa are available, e.g., in Awoniyi (2007), Bouafou (2007), Aniebo et al. (2008a), Aniebo \& Owen (2010) and Odesanya et al. (2011). Aniebo et al. (2008a) analyzed the nutrient composition of house fly maggots, in particular, crude protein, fat, fiber, ash and amino acid contents. They found that lysine and methionine, which are the two most limiting essential amino acids, were found to be higher in maggot meal than in fish meal and other conventional protein sources. However, the content changes with the drying method and with the age of the maggots; protein contents decreases and fat content increases with age (Aniebo \& Owen, 2010).

The sanitary risks related to house fly utilization in animal feed have been rather poorly investigated in Africa and elsewhere. Risks may occur for the animals themselves, for the consumers and for the breeders and populations in contact to rearing systems. Bouafou et al. (2011) showed that maggot meal could be toxic to rats, causing histological and histopathological damages. To our knowledge, this has not been demonstrated for poultry or fish. High proportions of maggot meals in poultry diet increased the mass of liver and gizzard (Téguia et al., 2002), but Pretorius (2011) did not observe the same effects on gizzard nor any toxicity effect using similar maggot meal diets. However, mass mortality of keets has been reported by farmers when they fed on maggots from decaying animals (Teye \& Adam, 2000), but the causal effect was not investigated. Fresh maggots and maggot meals contain various pathogenic microorganisms, as observed in Nigeria by Banjo et al. (2005) and Awoniyi (2007), respectively. Storage may increase the amount of pathogenic fungi and bacteria in maggot meals, especially if the moisture content is too high (Awoniyi et al., 2004). In his review, Awoniyi (2007) concluded that the inclusion of maggot meal in the poultry diet is microbiologically safe for the animal and the consumer, based on the facts that the same bacteria were isolated from chicken fed with various proportions of maggot meal and that the bacteria encountered in maggot meals are not really different from those encountered by animals and humans during their daily exploits. Nevertheless, health issues related to fresh maggots or maggot meals in animal feed should be further investigated. Adults of the house flies are known to transmit various animal and human diseases around the breeding facilities through carrying viruses, bacteria and protozoan parasites and tapeworms (Service, 1980; Ugbogu et al., 2006). Observations suggest that the exposure of 
substrates on farm in small maggot production systems does not increase house fly adult populations (Koné, unpublished data), but this needs to be verified appropriately.

\section{Black soldier fly larvae}

Black soldier flies, Hermetia illucens (Diptera Stratiomyiidae) have been tested and used extensively in many parts of the world to feed animals, particularly fish (Bondari \& Sheppard, 1987; St-Hilaire et al., 2007), but also swine (Newton et al., 1977) and poultry (Hale, 1973). However, this is not yet a common practice in West Africa. In Nigeria, Oluokun (2000) compared H. illucens larvae with soybean meal and fish meal on broiler production. The nutritional profile of maggots is comparable to fishmeal and, in some aspects, better than soybean meal. The author suggested that maggot meal could replace fish meal to upgrade the nutritive value of soybean meal in the broiler rations without any adverse effect on the weight gain, feed consumption and feed:gain ratio. Hem et al. (2008) tested the use of $H$. illucens for fish farming in Guinea. Maggots were obtained from natural oviposition on fermented palm kernel meal in open tanks. A diet of $30 \% \mathrm{H}$. illucens and $70 \%$ rice bran, based on dry matter, was given to tilapias and the growth rate was very satisfactory. The limiting factor was the low amount of larvae obtained through natural oviposition. However, more efficient rearing systems, including adult rearing and egg production, are available in other parts of the world (e.g. Newton et al., 2005; Hem, 2011). These systems could be easily adapted for West African situations and implemented at the farm or community level. A rearing system for $H$. illucens is presently being developed in Ghana as part of PROTEINSECT, an EU funded project (http://www.proteinsect.eu).

\section{Caterpillars}

Caterpillars, i.e. lepidopteran larvae, are more commonly used for human consumption than for animal feed, including in West Africa (van Huis, 2003, 2013). Cirina forda is a moth whose caterpillars defoliate shea trees, Vitellaria paradoxa, and which is commonly used in some parts of West Africa for human consumption. It is present only in the rainy season, during which enormous quantities can be harvested. In Nigeria, Oyegoke et al. (2006) evaluated the dietary potentials of the larvae of Cirina forda as poultry feed. They determined the performance of broiler chicks to the total or partial (50\%) replacement of fishmeal with the larvae of Cirina forda. They showed that the consumption rate, the mean weight gain and the specific growth rate of chicks fed entirely or partly with caterpillars did not differ significantly from those fed with conventional fish meal. Amao et al. (2010) evaluated Cirina forda larva meal on laying performance and egg characteristics of hens in Nigeria and concluded that it can replace up to $75 \%$ fish meal in the diet of laying hens without affecting feed intake, weight gain, egg production, feed efficiency and egg quality characteristics. At $100 \%$ replacement, however, daily egg production, egg weight and efficiency of feed utilization were significantly reduced. In the same country, Ijaiya \& Eko (2009) gradually substituted fish meal with silkworm, Anaphe infracta, caterpillar meal in broiler chicken feed. There was no significant difference in feed intake, body weight gain, feed conversion efficiency and protein efficiency ratio between the different treatments. They also determined that caterpillar meal was more cost effective than conventional fish meal. In Southern Africa, the caterpillar of the mopane moth, Imbrasia belina, also commonly consumed by humans, has been tested and used successfully for poultry feed (Moreki et al., 2012).

\section{Grasshoppers and crickets}

Extensive research has been carried out on the use and mass rearing of grasshoppers and crickets, particularly in Asia (Heuzé \& Tran, 2013b; van Huis et al., 2013). In West Africa, locusts and grasshoppers are used to feed animals on an opportunistic basis during outbreaks but recent studies in Nigeria have also considered their regular utilisation and nutritional properties for poultry and fish feed. Ojewola et al. (2005) and Adeyemo et al. (2008) investigated the nutritional potential of unspecified field-collected grasshoppers and desert locusts (Schistocerca gregaria), respectively, to replace fish meal as a protein source in broiler chicken diets. These experiments showed that locusts have a great potential as a more expensive protein source in broiler diets without reducing growth or causing physiological disorders. Another study, however, observed that undetermined grasshopper meal may depress weight gain and feed efficiency in broilers (Ojewola et al., 2003). Recent tests also showed that grasshopper meal could be integrated satisfactorily into African catfish feed (Nnaji \& Okoye, 2005 using unspecified grasshoppers; Alegbeleye $e t$ al., 2012 using Zonocerus variegatus) and Nile tilapia (Okoye \& Nnaji, 2005, using unspecified grasshoppers; Abanikannda, 2012; Emehinaiye, 2012, both using Locusta migratoria). All of these fish nutrition studies replaced fish meal with grasshopper meal in various proportions. Low proportions of grasshopper meal, i.e. up to $25 \%$ replacement of fish meal, provided similar or higher performances compared to fish meal, whereas higher proportions of grasshopper meal reduced growth and digestibility, possibly due to the lower protein value and higher level of crude fibre in grasshopper meal (Nnaji \& Okoye, 2005; Okoye \& Nnaji, 2005; Alegbeleye et al., 2012; Heuzé \& Tran, 2013b). The nutrient composition of grasshopper meal was assessed by Ojewola et al. (2003), Ojewola \& Udom (2005), Adeyemo et al. (2008) and Alegbeleye et al. (2012). Data from these and other studies, summarized in Heuzé \& Tran (2013b), were highly variable, e.g. with crude protein content varying from 29 to $66 \%$, probably because various species, developmental stages and processing methods were used. All studies on the use of grasshoppers as animal feed in West Africa have been made with field collected or laboratory reared grasshoppers. No production method for large scale production is described. Descriptions of tested production systems are available from other regions (Heuzé \& Tran, 2013b; van Huis et al., 2013).

\section{Other insects}

To our knowledge, no other insect species have been considered as permanent ingredients in animal feed in West Africa. In other regions, examples are more numerous. Mealworms, particularly Tenebrio molitor, have been the target of several studies in various areas of the world, e.g. Ramos Elorduy et al. (2002), for poultry and Ng et al. (2001) for fish. In East and Southeast Asia, larvae of chironomid flies are sold as live feed for aquarium fish and carnivorous fish (Shaw \& Mark, 1980; Hardouin \& Mahoux, 2003). In DRC, Munyuli Bin Mushambanyi \& Balezi (2002) have successfully mass produced cockroaches, Blatta orientalis, on poultry manure and used them satisfactorily as replacement for meat meal in poultry diet. More examples of insects used as animal feed elsewhere in the world are found in van Huis (2013) and van Huis et al. (2013)

\section{Perspective for the use of insects as animal feed in West Africa}

Many insects could potentially be used as a protein source to improve animal feed quality in West Africa and, indirectly, to improve food secu- 
rity. In the short term, the most promising insects appear to be flies, which can be reared on freely available organic waste material, in contrast to other insects such as grasshoppers, caterpillars and mealworms, which have to be produced on plants or plant products. Termites also need to be considered since they have been widely used in village poultry farming in the region for a long time. However, several issues remain and more research is needed before insects become widely adopted as a component of animal feed.

House flies are easy to rear and maggots can be produced in large quantities, as shown by recently developed industrial production systems in other parts of the world (Čičková et al., 2012; Coghlan, 2012). While similar industrial maggot-meal production systems could also be developed in West Africa for large-scale meat and fish producers, smallholder farmers and poor rural communities could adopt small-scale production systems on farm or at the community level by naturally exposing of organic waste substrate (Nzamujo, 1999; Hardouin \& Mahoux, 2003). Alternatively, simple adult rearing systems could provide the basis for community production systems that would distribute live or dry maggots to farmers. Priority research topics to allow the development and wide adoption of house fly maggots as feed include the following:

- Firstly, on-farm production systems need to be optimized. In particular, the most efficient and cost-effective substrates for maggot rearing need to be defined for the different eco-climatic regions and for the different seasons. Substrates need to be free, easily available and, if possible, accessible in all seasons. The use of domestic waste for fly rearing should also be considered for improving waste disposal and included in the environmental impact assessments of the production systems. Similarly, by-products of the fly rearing systems (substrate residues) can be excellent fertilizers or soil conditioners, but their quality is clearly variable and should be tested.

- Secondly, to develop small production units based on adult fly rearing for rural communities, the challenge will be to find simple methods for enhancing oviposition, egg collecting, larval extraction from the substrates and drying/storing. These methods are already partly available from systems used in Africa and elsewhere (Spiller, 1963; Hogsette, 1992; Koné, 1998; Nzamujo, 1999; Čičková et al., 2012) but could be improved or adapted for such rural production units.

- Thirdly, thile the nutritional properties and qualities of the house fly maggot are well known (see Bouafou, 2011; Heuzé \& Tran, 2013a, and this review), its suitability for some poultry species (e.g. guinea fowl, quails) and fish species needs to be further assessed. Furthermore, most studies on poultry were made with battery chickens and few data have been collected on their use with free range, scavenging poultry (Dankwa et al., 2002). For example, a specific issue for scavenging village poultry is the acceptability of dried insects compared to other available food sources, which should be assessed through behavioral tests.

- Finally, using house flies also implies some safety issues since these are known to carry various animal and human diseases (Ugbogu $e t$ al., 2006). Although non-quantified observations suggest that the exposure of substrates on-farm to attract flies in small maggot production systems does not increase house fly populations (Koné, unpublished data), this needs to be ascertained through rigorous measurements. The presence of animal diseases in maggot-based feed and the microbiological safety of the obtained meat product should also be investigated.

Black soldier flies have different properties. Specifically, since adults do not feed, they are much less prone than house flies to be vectors of pathogens and they are, thus, particularly safe. On the other hand, they grow more slowly than house flies and a continuous production system requires the rearing of adults in cages, which makes it less suitable for smallholder farmers with scavenging poultry. Nevertheless, it can be envisaged for poultry farmers and fish farmers. As for the house flies, techniques of adult and larval rearing, larval extractions, drying and storing need to be adapted to rural conditions of West Africa.
Termites cannot be easily mass reared and are known to produce methane, an important greenhouse gas (Hackstein \& Stumm, 1994). Therefore, large production systems cannot be envisaged. However, methods to facilitate termite collections on farm are already applied and could be further developed. Furthermore, the traditional use of termites as animal feed in West Africa is rather poorly known. Some termite species are known to be toxic to poultry but information is lacking for most species. Indigenous knowledge on this topic and on the use of termites as animal feed in general, should be investigated for the whole region. Indigenous knowledge should be confirmed by feeding tests as in Chrysostome (1997) and the causes of toxicity should be investigated.

No matter the insect species used, for each system using insects as feed, economic assessments need to be carried out and compared to the traditional system since only economically profitable methods are likely to be adopted. Furthermore, although insects represent a natural feed for animals in rural areas; the acceptability of eating animals fed with insects may have to be improved among some urban consumers. Finally, national policies on the use of insect-based animal feed are largely lacking. Therefore, there is a need to promote the use of insects as animal feed within the context of national policies on agriculture, nutrition, health, environment and development.

\section{References}

ABANIKANNDA M.F., 2012 - Nutrient digestibility and haematology of Nile tilapia (Oreochromis niloticus) fed with varying levels of locust (Locusta migratoria) meal. - Thesis dissertation, Federal University of Agriculture, Abeokuta, Ogun State, Nigeria.

ADENIJI A.A., 2007 - Effect of replacing groundnut cake with maggot meal in the diet of broilers. - Int. J. Poult. Sci. 6: 822-825.

ADENIJI A.A., 2008 - The feeding value of rumen content-maggot meal mixture in the diets of early weaned piglets. - Asian J. Anim. Vet. Adv. 3: 115-119.

ADESINA M.A., ADEJINMI 0.0., OMOLE A.J., FAYENUWO J.A., OSUNKEYE 0., 2011 - Performance of broilers' finishers fed graded levels of cassava peel-maggot meal-based diet mixtures. - J. Agr. For. Soc. Sci. 9: 226-231.

ADEYEMO G.O., LONGE 0.G., LAWAL H.A., 2008 - Effects of feeding desert locust meal (Schistocerca gregaria) on performance and haematology of broilers. Tropentag, 7-9 October 2008, Hohenheim, Germany. Available from: http:/www.tropentag.de/2008/abstracts/ abstracts.php? showtime $=0 \&$ noID $=1 \&$ menu $=11$

AGUNBIADE J.A., ADEYEMI 0.A., ASHIRU 0.M., AWOJOBI H.A., TAIWO A.A., OKE D.B., ADEKUNMIS A.A., 2007 - Replacement of fish meal with maggot meal in cassava-based layers' diets. - J. Poult. Sci. 44: 278-282.

AKPODIETE 0.J., INONI 0.E., 2000 - Economics of production of broiler chickens fed maggot meal as replacement for fish meal. - Nigerian J. Anim. Prod. 27: 59-63.

AKPODIETE O.J., OLOGHOBO A.D., ONIFADE A.A., 1998 - Maggot meal as a substitute for fish meal in laying chicken diet. - Ghana J. Agr. Sci. 31: 137-142.

ALEGBELEYE W.O., OBASA S.O., OLUDE 0.0., OTUBU K., JIMOH W., 2012 - Preliminary evaluation of the nutritive value of the variegated grasshopper (Zonocerus variegatus L.) for African catfish Clarias gariepinus (Burchell. 1822) fingerlings. - Aquacult. Res. 43: 412-420.

AMA0 0.A., OLADUNJOYE I.O., TOGUN V.A., OLUBAJO K., OYANIYI 0., 2010 - Effect of Westwood (Cirina forda) larva meal on the laying performance and egg characteristics of laying hen in a tropical environment. - Int. J. Poult. Sci. 9: 450-454.

ANIEBO A.0., OWEN 0.J., 2010 - Effects of age and method of drying on the proximate composition of housefly larvae (Musca domestica Linnaeus) Meal (HFLM). - Pakistan J. Nutr. 9: 485-487. 
ANIEBO A.0., ERONDU E.S., OWEN 0.J., 2008a - Proximate composition of housefly larvae (Musca domestica) meal generated from mixture of cattle blood and wheat bran. - Livestock Res. Rural Dev. 20: 205 .

ANIEBO A.O., ODUKWE C.A., EBENEBE C.I., AJUOGU P.K., OWEN O.J., ONU P.N., 2011 - Effect of housefly larvae (Musca domestica) meal on the carcass and sensory qualities of the mud catfish, (Clarias gariepinus). - Adv. Food Energy Secur. 1: 24-28.

ANIEBO A.O., WEKHE S.N., ERONDU E.S., OWEN O.J., NGODIGHA E.N., ISIRIMAH N.0., 2008b - Sustainable commercial maggot production (maggotry) for animal and aqua feeds in Rivers State, South Nigeria. - Int. J. Biotechnol. Biochem. 4: 197-205.

ATTEH J.O., OLOGBENLA F.D., 1993 - Replacement of fish meal with maggots in broiler diets: effects on performance and nutrient retention. - Nigerian J. Anim. Prod. 20: 44-49.

AWONIYI T.A.M., 2007 - Health, nutritional and consumers' acceptability assurance of maggot meal inclusion in livestock diet: a review. - Int. J. Tropic. Med. 2: 52-56.

AWONIYI T.A.M., ADETUYI F.C., AKINYOSOYE F.A., 2004 Microbiological investigation of maggot meal, stored for use as livestock feed component. - J. Food Agric. Environ. 2: 104-106.

AWONIYI T.A.M., ALETOR V.A., AINA J.M., 2003 - Performance of broiler - chickens fed on maggot meal in place of fishmeal. - Int. J. Poult. Sci. 2: 271-274.

BAMGBOSE A.M., 1999 - Utilization of maggot-meal in cockerel diets. Indian J. Anim. Sci. 69: 1056-1058.

BANJO A.D., LAWAL 0.A., ADEDUJI 0.0., 2005 - Bacteria and fungi isolated from housefly (Musca domestica L.) larvae. - Afr. J. Biotechnol. 4: 780-784.

BARONA E., RAMANKUTTY N., HYMAN G., COOMES 0.T., 2010 - The role of pasture and soybean in deforestation of the Brazilian Amazon. - Environ. Res. Let. 5: 024002.

BONDARI K., SHEPPARD D.C., 1987 - Soldier fly Hermetia illucens L., as feed for channel catfish, Ictalurus punctatus (Rafinesque), and blue tilapia, Oreochromis aureus (Steindachner). - Aquacult. Fish. Manage. 18: 209-220.

BOUAFOU K.G.M., 2007- Etude de la production d'asticots à partir d'ordures ménagères et de la valeur nutritionnelle de la farine d'asticots séchés (FAS) chez le rat en croissance. - Thesis dissertation, Université de Cocody, Abidjan, Côte d'Ivoire.

BOUAFOU K.G.M., 2011 - Revue bibliographique sur les asticots et leur emploi dans l'alimentation animale. - J. Anim. Plant Sci. 12: 15431551.

BOUAFOU K.G.M., KONAN B.A., MÉITÉ A., KOUAMÉ K.G., KATICOULIBALY S., 2011 - Substitution de la farine de poisson à la farine d'asticots séchés dans le régime du rat en croissance: risques pathologiques ? - Int. J. Biol. Chem. Sci. 5: 1298-1303.

BOUAFOU K.G.M., KOUAME K.G., AMOIKON E.K., OFFOUMOU A.M., 2006 - Potentiels pour la production d'asticots sur des sous-produits en Côte d'Ivoire. - Tropicultura 24: 157-161.

CHRYSOSTOME C.A.A.M., 1997 - Utilisation des termites pour le démarrage des pintadeaux; essai d'alimentation en milieu réel. pp 117-124 in: Proceedings Atelier RADAR, 9-13 Décember 1997. M'Bour, Sénégal.

CHRYSOSTOME C.A.A.M., COUBÉOU P.T., DAKPOGAN H., MENSAH G.A., 2009 - Comment collecter des termites avec des noix de rônier pour l'alimentation des pintadeaux? - Référentiel technicoéconomique pour la production avicole. Vol 1.

ČIČKOVÁ H., PASTOR B., KOZÁNEK M., MARTÍNEZ-SÁNCHEZ A., ROJO S., TAKÁ P., 2012 - Biodegradation of pig manure by the housefly, Musca domestica: a viable ecological strategy for pig manure management. - PLoS One 7: e32798.

COGHLAN A., 2012 - Extreme recycling turns poo into food. - New Sci. 216: $10-11$.
DANKWA D., NELSON F.S., ODDOYE E.O.K., DUNCAN J.L., 2002 Housefly larvae as a feed supplement for rural poultry. - Ghana J. Agric. Sci. 35: 185-187.

DEFOLIART G.R., 1995 - Edible insects as minilivestock. - Biodivers. Conserv. 4: 306-321.

DIAWARA M., 2013 - Impact the l'Utilisation des Termites en Aviculture Traditionelle au Burkina Faso. - Mémoire de Fin de Cycle. Université Polytechnique de Bobo-Dioulasso, Burkina Faso.

EBENSO I.E., UDO M.T., 2003 - Effect of live maggot on growth of the Nile perch, Oreochromis niloticus (Cichlidae) in South Eastern Nigeria. - Global J. Agric. Sci. 2: 72-73.

EMEHINAIYE P.A., 2012 - Growth performance of Oreochromis niloticus fingerlings fed with varying levels of migratory locust (Locusta migratoria) meal. - Thesis Dissertation. Federal University of Agriculture, Abeokuta, Nigeria.

FA0, 2010 - Promoting the contribution of edible forest insects in assuring food security. FAO forestry Department Programme. Forest Economy, Policy and Product divisions. FAO, Rome.

FA0, 2012 - State of the world fisheries. FA0, Rome.

FARINA L., DEMEY F., HARDOUIN J., 1991 - Production de termites pour l'aviculture villageoise au Togo. - Tropicultura 9: 181-187.

FASAKIN E.A., BALOGUN A.M., AJAYI 0.0., 2003 - Evaluation of full-fat and defatted maggot meals in the feeding of clariid catfish Clarias gariepinus fingerlings. - Aquacult. Res. 34: 733-738.

GODFRAY H.C.J., BEDDINGTON J.R., CRUTE I.R., HADDAD L., LAWRENCE D., MUIR J.F., PRETTY J., ROBINSON S., THOMAS S.M., TOULMIN C., 2010 - Food security: the challenge of feeding 9 billion people. - Science 327: 812-818.

HACKSTEIN J.H.P., STUMM C.K., 1994 - Methane production in terrestrial arthropods. - Proc. Natl. Acad. Sci USA. 91: 5441-5445.

HALE 0.M., 1973 - Dried Hermetia illucens larvae (Stratiomyidae) as a feed additive for poultry. - J. Georgia Entomol. Soc. 8: 16-20.

HARDOUIN J., 2003 - Production d'insectes à des fins économiques ou alimentaires: mini-élevage et BEDIM. - Notes fauniques de Gembloux 50: 15-25.

HARDOUIN J., MAHOUX G., 2003 - Zootechnie d'insectes - Elevage et utilisation au bénéfice de l'homme et de certains animaux. Bureau pour l'Echange et la Distribution de l'Information sur le Mini-élevage. BEDIM, Gembloux, Belgium.

HEM S., 2011 - Project FISH-DIVA. Maggot - Bioconversion Research Program in Indonesia. Concept of New Food Resources Results and Applications 2005-2011 Final Report. Centre for Aquaculture Research and Development Research Institute. Available from: http://www.indonesie.ird.fr/la-documentation/rapports2/bioconversion-research-program-in-indonesia-concept-of-new-foodresources-results-and-applications-2005-2011.

HEM S., TOURE S., SAGBLA C., LEGENDRE M., 2008 - Bioconversion of palm kernel meal for aquaculture: Experiences from the forest region (Republic of Guinea). - Afr. J. Biotechnol. 7: 1192-1198.

HEUZÉ V., TRAN G., 2013a - Housefly maggot meal. Feedipedia.org. A programme by INRA, CIRAD, AFZ and FAO. Available from: http://www.feedipedia.org/node/671.

HEUZÉ V., TRAN G., 2013b - Locust meal, locusts, grasshoppers and crickets. Feedipedia.org. A programme by INRA, CIRAD, AFZ and FA0. Available from: http://www.feedipedia.org/node/198

HOGSETTE J.A., 1992 - New diets for production of house flies and stable flies (Diptera: Muscidae) in the Laboratory. - J. Econ. Entomol. 85: 2291-2294.

IDOWU A.B., AMUSAN A.A.S., OYEDIRAN A.G., 2003 - The response of Clarias gariepinus fingerlings (Burchell 1822) to the diet containing housefly maggot (Musca domestica) (L). - Nigerian J. Anim. Prod. 30: 139-144.

IJAIYA A.T., EKO E.0., 2009 - Effect of replacing dietary fish meal with silkworm (Anaphe infracta) caterpillar meal on performance, car- 
cass characteristics and haematological parameters of finishing broiler chicken. - Pakistan J. Nutr. 8: 850-855.

KAREEM A.O., OGUNREMI J.B., 2012 - Growth performance of Clarias gariepinus fed compounded rations and maggots. - J. Env. Issues Agr. Devel. Countries 4: 1-5.

KONÉ N'G., 1998 - Mise au point d'un Procédé industriel de production de larves de mouche (asticots). - Document de Brevet $\mathrm{N}^{\circ} 10808$ de l'Organisation Africaine de la Propriété Intellectuelle (OAPI) du 30 juin 1999 .

LOA C., 2000 - Production et utilisation contrôlées d'asticots. Tropicultura 18: 215-219.

MADU C.T., UFODIKE, E.B.C., 2003 - Growth and survival of catfish (Clarias anguillaris) juveniles fed live tilapia and maggot as unconventional diets. - J. Aquatic Sci. 18: 47-51.

MBUNWEN F.N.H., ONYIMONYI A.E., NWOGA C.C., MUSONGONG G.A., 2011 - Biological value of maggot meal as a replacement for fishmeal in the diets of African giant Snail (Achatina spp.) hatchings. - J. Life Sci. 5: 821-825.

MENSAH G.A., POMALEGNI S.C.B., KOUDJOU A.L., CAKPOVI J.C.G, ADJAHOUTONON K.Y.K.B., AGOUNDO A., 2007 - Farine d'asticots de mouche, une source de protéines bien valorisée dans l'alimentation des canards de barbarie. - Poster presented at ler Colloque de l'UAC des Sciences et Cultures à Abomey-Calavi (Bénin), 24 29/06/2007. Atelier III: Sciences Naturelles et Agronomiques.

MOREKI J.C., TIROESELE B., CHIRIPASI S.C., 2012 - Prospects of utilizing insects as alternative sources of protein in poultry diets in Botswana: a review. - J. Anim. Sci. Adv. 2: 649-658.

MPOAME M., TEGUIA A., NGUEMFO E.L., 2004 - Essai comparé de production d'asticots dans les fientes de poule et dans la bouse de vache. - Tropicultura 22: 84-87.

MUNYULI BIN MUSHAMBANYI T., BALEZI N., 2002 - Utilisation des blattes et des termites comme substituts potentiels de la farine de viande dans l'alimentation des poulets de chair au Sud-Kivu, République Démocratique du Congo. - Tropicultura 20: 10-16.

NEWTON G.L., BOORAM C.V., BARKER R.W., HALE O.M., 1977 - Dried Hermetia illucens larvae meal as supplement for swine. - J. Anim. Sci. 44: 395-400.

NEWTON L., SHEPPARD C., WATSON D.W., BURTLE G., 2005 - Using the black soldier fly, Hermetia illucens, as a value-added tool for the management of swine manure. - North Carolina, North Carolina State University. Available from: www.cals.ncsu.edu/waste_mgt/ smithfield_projects/phase2report05/cd,web\%20files/A2.pdf.

NG W.K., LIEW F.L., ANG L.P., WONG K.W., 2001 - Potential of mealworm (Tenebrio molitor) as an alternative protein source in practical diets for African catfish, Clarias gariepinus. - Aquacult. Res. 32: 273-280.

NNAJI C.J., OKOYE F.C., 2005 - Substituting fish meal with grasshopper meal in the diet of Clarias gariepinus fingerlings. pp. 30-36. In: Proceedings of the 19th Annual Conference of the Fisheries Society of Nigeria (FISON), 29 Nov - 03 Dec 2004 , Ilorin, Nigeria.

NTUKUYOH A.I., UDIONG D.S., IKPE E., AKPAKPAN A.E., 2012 Evaluation of nutritional value of termites (Macrotermes bellicosus): soldiers, workers, and queen in the Niger Delta region of Nigeria. - Int. J. Food Nutr. Safety 1: 60-65.

NZAMUJO 0.P., 1999 - Technique for maggot production. The Songhai experience. Report.

ODESANYA B.O., AJAYI S.O., AGBAOGUN B.K.O., OKUNEYE B., 2011 Comparative evaluation of nutritive value of maggots. - Int. J. Sci. Engin. Res. 2: 1-5.

OGUNJI J.O., KLOAS W., WIRTH M., NEUMANN N., PIETSCH C., 2008a - Effect of housefly maggot meal (magmeal) diets on the performance, concentration of plasma glucose, cortisol and blood characteristics of Oreochromis niloticus fingerlings. - J. Anim. Physiol. Anim. Nutr. 92: 511-518.
OGUNJI J.O., KLOAS W., WIRTH M., SCHULZ C., RENNERT B., 2006 Housefly maggot meal (Magmeal): an emerging substitute of fishmeal in tilapia diets. Tropentag 2006. Hohenheim. Available from: http://www.tropentag.de/2006/abstracts/full/76.pdf.

OGUNJI J.O., KLOAS W., WIRTH M., SCHULZ C., RENNERT B., 2008b Housefly maggot meal (magmeal) as a protein source for Oreochromis niloticus (Linn.). - Asian Fisheries Sci. 21: 319-331.

OGUNJI J.0., NIMPTSCH J., WIEGAND C., SCHULZ C., 2007 Evaluation of the influence of housefly maggot meal (magmeal) diets on catalase, glutathione S-transferase and glycogen concentration in the liver of fingerling. - Comp. Biochem. Physiol. A Mol. Integr. Physiol. 147: 942-947.

OGUNJI J., NIMPTSCH J., WIEGAND C., SCHULZ C., RENNERT B., 2011 - Effect of housefly maggot meal (magmeal) diets on catalase, and glutathione S-transferase in the liver and gills of carp Cyprinus carpio fingerling. - Int. Aquat. Res. 2: 39-44.

OGUNJI J., PAGEL T., SCHULZ C., KLOAS W., 2009 - Apparent digestibility coefficient of housefly maggot meal (magmeal) for Nile tilapia (Oreochromis niloticus L.) and carp (Cyprinus carpio). - Asian Fisheries Sci. 22: 1095-1105.

OJEWOLA G.S., UDOM S.F., 2005 - Chemical evaluation of the nutrient composition of some unconventional animal protein sources. - Int. J. Poultry Sci. 4: 745-747.

OJEWOLA G.S., EBURUAJA A.S., OKOYE F.C., LAWAL A.S., AKINMUTIMI A.H., 2003 - Effect of inclusion of grasshopper meal on performance, nutrient utilization and organ of broiler chicken. - J. Sustain. Agric. Environ. 5: 19-25.

OJEWOLA G.S., OKOYE F.C., UKOHA 0.A., 2005 - Comparative utilization of three animal protein sources by broiler chickens. - Int. J. Poultry Sci. 4: 462-467.

OKAH U., ONWUJIARIRI E.B., 2012 - Performance of finisher broiler chickens fed maggot meal as a replacement for fish meal. - J. Agr. Technol. 8: 471-477.

OKOYE F.C., NNAJI J.C., 2005 - Effects of substituting fish meal with grasshopper meal on growth and food utilization of the Nile Tilapia, Oreochromis niloticus fingerlings. pp. 37-44. In: 19th Annual Conference of the Fisheries Society of Nigeria (FISON), 29 Nov - 03 Dec 2004. Ilorin, Nigeria.

OLELE N.F., 2011 - Comparative study on the use of natural and artificial based feeds for the culture of Clarias gariepinus fingerlings. J. Agr. Biol. Sci. 6: 9-13.

OLUOKUN J.A., 2000 - Upgrading the nutritive value of full-fat soyabean meal for broiler production with either fishmeal or black soldier fly larvae meal (Hermetia illucens). - Nigerian J. Anim. Sci. 1: 51-61.

OMOLE A.J., OGBOSUKA G.E., SALAKO R.A., AJAYI 0.0., 2005 - Effect of replacing oyster shell with gypsum in broiler finisher diet. - J. Appl. Sci. Res. 1: 245-248.

OMOYINMI G.A.K., OLAOYE 0.J., 2012 - Growth performance of Nile tilapia-Oreochromis niloticus fed diets containing different sources of animal protein. - Libyan Res. Center J. Int. 3: 18-23.

OSSEY Y.B., KOUMI A.R., KOFFI K.M., ATSE B.C., KOUAME L.P., 2012 Utilisation du soja, de la cervelle bovine et de l'asticot comme sources de protéines alimentaires chez les larves de Heterobranchus longifilis (Valenciennes, 1840). - J. Anim. Plant Sci. 15: 2099-2108.

OYEGOKE 0.0., AKINTOLA A.J., FASORANTI J.0., 2006 - Dietary potentials of the edible larvae of Cirina forda (westwood) as a poultry feed. - Afr. J. Biotechnol. 5:1799-1802.

OYELESE 0.A., 2007 - Utilization of compounded ration and maggot in the diet of Clarias gariepinus. - Res. J. Appl. Sci. 2: 301-306.

POUSGA S., BOLY H., LINDBERG J.E., OGLE B., 2005 - Scavenging chickens in Burkina Faso: Effect of season, location and breed on feed and nutrient intake. - Trop. Anim. Health Prod. 37: 623-634.

PRETORIUS Q., 2011 - The evaluation of larvae of Musca Domestica 
(common house fly) as protein source for broiler production. Thesis dissertation. University of Stellenbosch, South Africa.

RAMOS ELORDUY J., GONZALEZ E.A., HERNANDEZ A.R., PINO, J.M., 2002 - Use of Tenebrio molitor (Coleoptera: Tenebrionidae) to recycle organic wastes and as feed for broiler chickens. - J. Econ. Entomol. 95: 214-220.

RAVINDRAN V., BLAIR R., 1993 - Feed resources for poultry production in Asia and the Pacific. - World Poulty Sci. J. 49: 219-235.

REDFORD K.H., DOREA J.G., 1984 - The nutritional value of invertebrates with emphasis on ants and termites as food for mammals. J. Zool. 203: 385-395.

RHODES UNIVERSITY, 2010 - A manual for rural freshwater aquaculture, rural fisheries programme. - Rhodes, South Africa.

RUMPOLD B.A., SCHLÜTER 0.K., 2013 - Nutritional composition and safety aspects of edible insects. - Mol. Nutr. Food Res. 57: 802-823.

RUTAISIRE J., 2007 - Analysis of feeds and fertilizers for sustainable aquaculture development in Uganda. - In: HASAN M.R., HECHT T., DE SILVA S.S., TACON A.G., (eds). Study and analysis of feeds and fertilizers for sustainable aquaculture development. FAO Fisheries Technical Paper. No. 497. Rome, FA0: pp 471-487.

SERVICE M.V., 1980 - A guide to medical entomology. - The Macmillan Press Ltd, London.

SHAW P.C., MARK K.K., 1980 - Chironomid farming - a means of recycling farm manure and potentially reducing water pollution in Hong Kong. - Aquaculture 21: 155-163.

SOGBESAN A.0., UGWUMBA A.A.A., 2008 - Nutritive evaluation of termite (Macrotemes subhyalinus) as animal protein supplements in the in the diet of Heterobranchus longifilis (Valenciennes, 1840) fingerlings. - Turkish J. Fisheries Aquat. Sci. 8: 149-157.
SOGBESAN A.0., AJUONU N., MUSA B.O., ADEWOLE A.M., 2006 Harvesting techniques and evaluation of maggot meal as animal dietary protein source for Heteoclarias in outdoor concrete tanks. World J. Agr. Sci. 4: 394-402.

SPILLER D., 1963 - Procedure for rearing houseflies. - Nature 199: 405.

ST-HILAIRE S., SHEPPARD C., TOMBERLIN J.K., IRVING S., NEWTON L., MCGUIRE M.A., MOSLEY E.E., HARDY R.W., SEALEY W., 2007 Fly prepupae as a feedstuff for rainbow trout, Oncorhynchus mykiss. - J. World Aquacult. Soc. 38:59-67.

TÉGUIA A., MPOAME M., MBA J.A.0., 2002 - The production performance of broiler birds as affected by the replacement of fish meal by maggot meal in the starter and finisher diets. - Tropicultura 20: 187-192.

TEYE G.A., ADAM M., 2000 - Constraints to Guinea fowl production in northern Ghana: a case study of the Damongo area. - Ghana J. Agr. Sci. 33:153-157.

UGBOGU 0.C., NWACHUKWU N.C., OGBUAGU U.N., 2006 - Isolation of Salmonella and Shigella species from house flies (Musca domestica l.) in Uturu, Nigeria. - Afr. J. Biotechnol. 5: 1090-1091.

VAN HUIS A., 2003 - Insects as food in sub-Saharan Africa. - Insect Sci. Appl. 23:163-85.

VAN HUIS A., 2013 - Potential of insects as food and feed in assuring food security. - Ann. Rev. Entomol. 58: 563-583.

VAN HUIS A., VAN ITTERBEECK J., KLUNDER H., MERTENS E., HALLORAN A., MUIR G., VANTOMME P., 2013 - Edible insects Future prospects for food and feed security. - FAO Forestry Paper 171.

VORSTERS A., AMINOU T., DEMEY F., 1994 - Récolte de termites pour l'aviculture à Songhai (Bénin). - Cahiers Agr. 3: 265-266. 